ACTA UNIVERSITATIS LODZIENSIS

FOLIA LITTERARIA POLONICA 3(41) 2017

http://dx.doi.org/10.18778/1505-9057.41.12

Anita Szwajkowska*

\title{
Tytus, Romek i A'Tomek z perspektywy komunikatywizmu
}

\author{
A'Tomek: Uwaga! Kanat Kiloński pod nami. \\ Dlugość 98,7 km, głębokość 11,3 m, zbudowany w roku $1895^{1}$. \\ Romek: Po co podajesz te dane? \\ A'Tomek: Bo nasza książeczka ma nie tylko bawić, ale i uczyć. \\ Śmiech dla śmiechu to niepotrzebna strata chichotów ${ }^{2}$.
}

Tymi oto słowami, na dziesiątej stronie Księgi $V$ przygód Tytusa, Romka i A'Tomka, jej autor, Henryk Jerzy Chmielewski (Papcio Chmiel) wyraźnie wskazuje na zasadniczą myśl przyświecającą mu w procesie tworzenia: „ucząc bawić, bawiąc uczyć". Jest rok 1970, komiks w formie zeszytu³ ukazuje się cyklicznie (raz do roku) od czterech lat. Każdy z numerów jest poddawany wnikliwej cenzurze Głównego Urzędu Kontroli Prasy, Publikacji i Widowisk i będzie tak aż do opublikowania Księgi XVIII przygód Tytusa. Do tego też czasu Wydawnictwo Harcerskie będzie narzucało treści, jakie powinny być zawarte w książeczkach. Przygody, w których do roku 1987 weźmie udział trójka bohaterów, będą miały wyraźny cel dydaktyczny, kształtujący młodych czytelników na odpowiedzialnych uczestników życia zbiorowego Polskiej Rzeczypospolitej Ludowej.

Niniejszy artykuł nie stanowi próby udzielenia odpowiedzi na pytanie: czy wątki propagandowe są obecne w analizowanych komiksach. Tytus, Romek i A'Tomek bowiem, jak każdy „szanujący się” tekst z doby realnego socjalizmu, łączy w sobie typowy dla utworów literacko-rozrywkowych cel estetyczny z funkcją kształtowania opinii społecznej. Dlatego też już u jego podstaw legło przekonanie o retorycznym charakterze przekazu. Praktyczny wymiar retoryki,

\footnotetext{
* Mgr, e-mail: szwajkowskaanita@interia.pl; Uniwersytet Łódzki, Wydział Filologiczny, Katedra Dziennikarstwa i Komunikacji Społecznej.

${ }^{1}$ Wszystkie wypowiedzi bohaterów komiksu Tytus, Romek i A'Tomek zapisuję kursywą.

${ }^{2}$ H.J. Chmielewski, Tytus, Romek i A'Tomek. Księga V, Wydawnictwo Harcerskie, Warszawa 1970, s. 10.

${ }^{3}$ Przygody Tytusa, Romka i A'Tomka ukazywały się od 1957 roku w harcerskiej gazecie „Świat Młodych”. Przez dziewięć lat czytelnicy na ostatniej stronie pisma odnajdowali w czarno-białych odcinkach historyjki o Tytusie i dwójce jego przyjaciół.
} 
określanej zazwyczaj jako „sztuka przekonywania” mająca na celu „przede wszystkim kształtowanie poglądów, nakłanianie innych ludzi do przyjęcia pewnej postawy lub wywieranie wpływu na ich działania"4, jest wszechobecny w historyjkach Papcia Chmiela. Zasadnicze pytanie nie brzmi więc: czy?, ale: w jaki sposób? Przy pomocy jakich wyznaczników o charakterze formalnym i nieformalnym młody odbiorca poznaje i utrwala normy oraz reguły obowiązujące w społeczeństwie.

Głównym przedmiotem obserwacji są - wyodrębnione i opisane na gruncie gramatyki komunikacyjnej przez Aleksego Awdiejewa i Grażynę Habrajską - typowe dla stylu publicystycznego środki językowe oraz odtworzona argumentacja aksjologiczna ${ }^{5}$. Wybór metodologii opracowanej przez twórców polskiej szkoły komunikatywizmu wydaje się o tyle uzasadniony, że daje możliwość holistycznego przyjrzenia się zagadnieniu, a tym samym umożliwia opis szeregu komponentów ukrytych. Komunikatywiści, powołując się na myśl Ludwiga Wittgensteina: „słowo zyskuje znaczenie dopiero w jego użyciu”, opracowali metodologię, u podstaw której znalazło się socjo-funkcjonalne podejście do języka autorstwa Michaela Hallidaya. Badacz ten, pozostając pod wpływem funkcjonalizmu praskiego i francuskiego, zainspirowany poglądami propagowanymi w Szkole Londyńskiej, opisał metafunkcje (ideacyjną, interpersonalną i tekstową), które oddają relacje między systemem języka a jego użyciem w sytuacji komunikacyjnej, czyli w konkretnym tekście ${ }^{7}$. Awdiejew i Habrajska również rozbili proces kontaktu językowego na trzy funkcjonalnie różne płaszczyzny: ideacyjną, interakcyjną i tekstową operujące odrębnymi typami sensu, zaznaczając jednocześnie, że komunikowanie jest jednolitym procesem tworzącym złożoną całość znaczeniową.

Na poziomie ideacyjnym gramatyki komunikacyjnej opisywane są rozmaite sposoby obrazowania świata przy użyciu języka. Przekazywane informacje mogą dotyczyć zarówno rzeczywistości realnie istniejącej, jak również wyobrażeń twórców komunikatu. Na poziomie interakcyjnym osoba komunikująca w subiektywny sposób informuje odbiorcę, jaki cel realizuje jej działanie werbalne. Innymi słowy: poziom interakcyjny określa stosunek mówiącego do tej rzeczywistości. Poziom tekstowy jest wynikiem próby włączenia problematyki stylistycznej do metodologii komunikatywizmu. Awdiejew i Habrajska, porusza-

\footnotetext{
${ }^{4}$ G. Bonsiepe, Retoryka wizualno-werbalna, przeł. M.B. Fedewicz, „Pamiętnik Literacki” 1985, R. 76, z. 3, s. 303.

${ }^{5}$ A. Awdiejew, G. Habrajska, Wprowadzenie do gramatyki komunikacyjnej, Oficyna Wydawnicza LEKSEM, t. 2, Łask 2006.

${ }^{6}$ A. Awdiejew, G. Habrajska, Komponowanie sensu w procesie odbioru komunikatów, Primum Verbum, Łódź 2010, s. 70.

${ }^{7}$ M.A. Paveau, G.E. Sarfati, Wielkie teorie językoznawcze. Od językoznawstwa historyczno-porównawczego do pragmatyki, tłum. I. Piechnik, Wydawnictwo AVALON, Kraków 2009, s. 158.
} 
jąc trudny temat funkcjonalnej klasyfikacji języka polskiego, wyodrębniają na poziomie gramatyki organizacji dyskursu pięć gatunków: potoczny, naukowy, urzędowy, publicystyczny i literacki. Za kryterium przyjmują przeznaczenie komunikacyjne danego stylu: „W tym ujęciu gatunek i styl w różny sposób wskazują na ten sam tekst i w tym zakresie można je utożsamiać. Gatunek jest określony

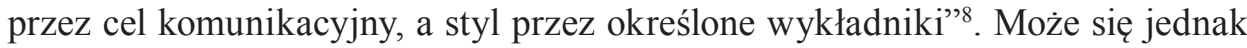
zdarzyć tak, że w jednym tekście uważny odbiorca odnajdzie cechy reprezentatywne różnych stylów. Tak jest właśnie w przypadku komiksu Tytus, Romek i A'Tomek, który łączy w sobie cechy stylu literackiego i publicystycznego. Obok wyraźnego skupienia autora na formie i dążności do wywołania przeżycia estetycznego przekaz wzbogacony zostaje rzetelną wiedzą (tzw. literatura dydaktyczna) służącą do wpajania norm moralnych i określonego systemu wartości 9 .

Materiał, na podstawie którego prześledzę dążenia Chmielewskiego do wpływania na odbiorców, wyekscerpowałam z sześciu ksiąg przygód Tytusa, Romka i A'Tomka. Chcąc ukazać nie tylko koloryt, ale przede wszystkim zmienność epoki, wybrałam po dwie księgi z okresu rządów każdego z pierwszych sekretarzy KC PZPR. I tak:

1) Rządy Władysława Gomułki

a) Ksiegga $I^{10}$ z 1966 roku, w której Tytus zostaje harcerzem, stanowi odpowiedź nie tyle na oczekiwania czytelników, co jest zaplanowanym „dzieckiem” systemu gomułkowskiego, dopuszczającego pewien margines swobód (wydanie komiksu w formie książeczki!) oraz propagującego przynależność do organizacji młodzieżowej - Związku Harcerstwa Polskiego;

b) Księga $I V^{11}$ z 1969 roku opowiada o zaszczytnej przynależności do innej mundurowej organizacji państwowej - Wojska Polskiego. Ukazanie potęgi polskiej armii zbiega się w czasie z rocznicą 25-lecia PRL.

2) Rządy Edwarda Gierka

c) Księga VIII ${ }^{12}$ z 1973 roku - Roku Kopernikowskiego, stanowi kolejny dowód na to, że uroczystości były tak pozbawione umiaru, iż sprawiały wrażenie, jakoby władzom zależało na ośmieszeniu postaci Mikołaja Kopernika w świadomości społecznej ${ }^{13}$;

d) Ksiegga XI $I^{14} \mathrm{z} 1977$ roku sprowadza ludyczny charakter lektury Tytusa ... do silnego środka perswazyjnego - działajcie na rzecz ratowania polskich zabytków!

\footnotetext{
${ }^{8}$ A. Awdiejew, G. Habrajska, Wprowadzenie..., s. 191.

9 Tamże, s. 341-347.

${ }^{10}$ H.J. Chmielewski, Tytus, Romek i A'Tomek. Księga I, Prószyński Media, Warszawa 2009.

${ }^{11}$ H.J. Chmielewski, Tytus, Romek i A’Tomek. Księga IV, Prószyński Media, Warszawa 2009.

${ }^{12}$ H.J. Chmielewski, Tytus, Romek i A’Tomek. Ksiega VIII, Prószyński Media, Warszawa 2009.

13 A.L. Sowa, Historia polityczna Polski 1944-1991, Wydawnictwo Literackie, Kraków 2011.

${ }^{14}$ H.J. Chmielewski, Tytus, Romek i A’Tomek. Księga XI, Prószyński Media, Warszawa 2009.
} 
3) Rządy Wojciecha Jaruzelskiego

e) Ksiegga $X V I^{15}$ z 1982 roku to ukazany w krzywym zwierciadle, a jednak całkiem rzeczywisty, obraz polskiego dziennikarstwa.

f) Księga XVIII ${ }^{16}$ z 1987 roku to odważnie czerpiąca z komiksowych trendów Europy Zachodniej i Stanów Zjednoczonych kubistyczna wizja - nie tylko malarstwa.

Pomimo że w kręgu moich zainteresowań nie pozostają zachowania perswazyjne o charakterze wizualnym, zestawiając dane w tabelach pokażę, jak ewoluowała szata graficzna komiksów. Pamiętając o zastrzeżeniach, z jakimi spotkał się Chmielewski, rysując pierwszą książeczkę: „Chmielu, tylko żadnych BUM, BĘC! Kolory niekrzykliwe, żeby nie przypominały komiksów zachodnich"17, przedstawię przebieg procesu łagodzenia cenzury, także na tej płaszczyźnie. Rezygnując ze szczegółowości, w opisie elementów graficznych uwzględniam jedynie trzy zmienne: kolorystykę komiksu (Tab. 1), układ i rodzaj ramek okalających obrazki (Tab. 2) oraz charakter użytej czcionki i umiejscowienie napisów (Tab. 3).

Tabela 1. Kolorystyka komiksu Tytus, Romek i A’Tomek - wybrane księgi

\begin{tabular}{|l|c|c|c|}
\hline & $\begin{array}{c}\text { co druga strona } \\
\text { kolorowa }\end{array}$ & $\begin{array}{c}\text { wszystkie strony } \\
\text { kolorowe }\end{array}$ & barwne to dymków \\
\hline Księga I & TAK & - & - \\
\hline Księga IV & TAK & - & - \\
\hline Księga VIII & TAK & - & - \\
\hline Księga XI & - & TAK & 33 dymki \\
\hline Księga XVI & - & TAK & 34 dymki \\
\hline Księga XVIII & - & TAK & 87 dymków \\
\hline
\end{tabular}

Źródło: oprac. własne.

${ }^{15}$ H.J. Chmielewski, Tytus, Romek i A’Tomek. Księga XVI, Prószyński Media, Warszawa 2009.

${ }^{16}$ H.J. Chmielewski, Tytus, Romek i A’Tomek. Księga XVIII, Prószyński Media, Warszawa 2009.

${ }^{17}$ H.J. Chmielewski, Tytus zlustrowany. Autobiografia na tle historii komiksu pod tytułem „Tytus, Romek i A’Tomek", Młodzieżowy Dom Kultury w Opolu, Opole 2006; cyt. za: H.J. Chmielewski, Tytus, Romek i A’Tomek. Księga I, Prószyński Media, Warszawa 2009, s. 56. 
Tabela 2. Ramki w komiksie Tytus, Romek i A’Tomek - wybrane księgi

\begin{tabular}{|c|c|c|c|c|c|c|c|}
\hline & 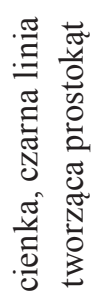 & 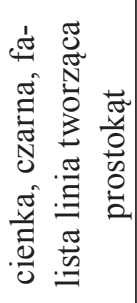 & 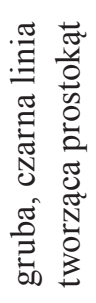 & 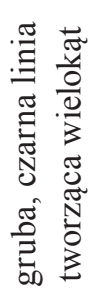 & 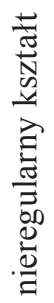 & 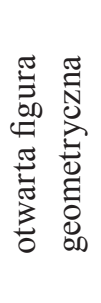 & 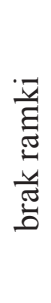 \\
\hline Księga I & 249 & - & - & - & - & - & - \\
\hline Księga IV & 188 & - & 6 & - & 1 & - & 31 \\
\hline Księga VIII & - & - & 229 & 22 & - & - & 25 \\
\hline Księga XI & - & - & 322 & 38 & 1 & 4 & 2 \\
\hline Księga XVI & - & 12 & 335 & 5 & - & - & 1 \\
\hline Księga XVIII & - & - & 211 & 88 & - & - & 1 \\
\hline
\end{tabular}

Źródło: oprac. własne.

Tabela 3. Czcionka w komiksie Tytus, Romek i A’Tomek - wybrane księgi

\begin{tabular}{|l|c|c|c|c|}
\hline \multirow{2}{*}{} & \multicolumn{2}{|c|}{ napisy w dymkach } & \multicolumn{2}{c|}{ napisy poza dymkami } \\
\cline { 2 - 5 } & $\begin{array}{c}\text { czcionka } \\
\text { klasyczna }\end{array}$ & $\begin{array}{c}\text { czcionka } \\
\text { modyfikowana }\end{array}$ & $\begin{array}{c}\text { czcionka } \\
\text { klasyczna }\end{array}$ & $\begin{array}{c}\text { czcionka } \\
\text { modyfikowana }\end{array}$ \\
\hline Księga I & 283 & 18 & 15 & 20 \\
\hline Księga IV & 247 & 45 & 5 & 22 \\
\hline Księga VIII & 301 & 51 & - & 36 \\
\hline Księga XI & 423 & 71 & 16 & 47 \\
\hline Księga XVI & 377 & 77 & 13 & 37 \\
\hline Księga XVIII & 297 & 66 & 4 & 50 \\
\hline
\end{tabular}

Źródło: oprac. własne.

Z każdym kolejnym numerem obserwujemy większą swobodę $\mathrm{w}$ doborze wizualnych środków wyrazu. Wraz z rosnącym stopniem skomplikowania przekazu obrazkowego następuje wyraźna zmiana sposobu promowania pożądanych wzorców, zmienia się również kierunek kształtowanych postaw.

Wpływanie na odbiorców jako efekt zastosowania siły perswazyjnej języka - jak już wspomniałam - jest charakterystyczne dla stylu publicystycznego. Poniżej, wykorzystując narzędzia badawcze komunikatywizmu, przyglądam się istniejącym w tekście środkom perswazji. Nie zastanawiam się nad ich skutecznością, a jedynie ograniczam do stwierdzenia ich występowania. Istotna okazuje 
się dla mnie propozycja Awdiejewa i Habrajskiej, aby środki perswazyjne obecne w dyskursie publicystycznym podzielić na jawnie wyrażone w tekście, czyli o charakterze formalnym, oraz znajdujące odzwierciedlenie jedynie w organizacji treści, czyli nieformalne ${ }^{18}$. Badacze, odpowiadając na zapotrzebowanie współczesnego językoznawstwa, usiłują

przezwyciężyć słabości istniejących metodologii cząstkowych opisów językowych, takich jak na przykład strukturalizm, funkcjonalizm czy generatywizm przez wprowadzenie podejścia holistycznego, które pozwala bez odrzucania dorobku tych wszystkich orientacji wykorzystać go z nieco ogólniejszej perspektywy opisu językowego ${ }^{19}$.

Zasadność owego „połączenia wspólnych sił” dostrzegamy wraz z uświadomieniem sobie, iż nawet najkrótsza sytuacja komunikacyjna, obok form językowych, bogata jest w szereg komponentów ukrytych.

Dlatego też, mając na uwadze założenia, z których wyrasta komunikatywizm, a także pamiętając o artystycznym charakterze obrazowania świata całkowicie fikcyjnego, proponuję niewielką modyfikację wyraźnie dychotomicznego podziału środków perswazyjnych występujących w dyskursie publicystycznym. Aby w pełni uchwycić proces wywierania wpływu na młodych czytelników, wyodrębniam i opisuję trzy płaszczyzny, na których dochodzi do próby kreowania poglądów w komiksach Tytus, Romek i A'Tomek. Poziom pierwszy obejmuje zachowania językowe bohaterów, a wśród nich: ekspresywnie nacechowaną leksykę i frazeologię, utarte zwroty i frazy, slogany, hasła i apele, szablony, klisze oraz frazemy blokujące weryfikację. Drugi poziom perswazyjności przekazu, pomimo że wyprowadzony z tekstu, nie przynależy do niego w całości, ale częściowo jest odtwarzany. To argumentacja o charakterze aksjologicznym. Ostatni, trzeci poziom nie pozostaje już w ścisłej łączności z zachowaniami językowymi. Jego obecność w komiksie odkrywamy przez dobór i sposób ukazania tematu, komunikację wizualną, wykorzystane stereotypy, nienazwane emocje i idee, a także przez „wszystkie chwyty nadawcy, dążące do utworzenia tzw. ramy perswazyjnej, czyli kreowania postaci nadawcy i odbiorcy oraz budowania więzi między nimi”20.

Poniżej zamieszczam przykłady wszystkich wyznaczników tekstu publicystycznego, wraz z krótkim komentarzem ilustrującym proces celowego i w pełni świadomego poddawania odbiorcy perswazji. Przy czym cel perswazyjny nadawcy może, ale w żadnym razie nie musi, pozostawać w zgodzie z wyznawaną przez niego ideologią.

${ }^{18}$ A. Awdiejew, G. Habrajska, Wprowadzenie..., s. 257-258.

${ }^{19}$ A. Awdiejew, Komunikatywizm (perspektywa metodologiczna badań lingwistycznych), [w:] Język w komunikacji 1, red. G. Habrajska, Wydawnictwo Wyższej Szkoły Humanistyczno-Ekonomicznej, Łódź 2001, s. 23.

${ }^{20}$ A. Awdiejew, G. Habrajska, Wprowadzenie..., s. 264. 


\section{Perswazja zamknięta w słowie}

Perswazyjny sens użytych ekspresywizmów służy budowaniu w świadomości czytelników trwałych wyobrażeń społecznych na temat zachowań oraz przekonań akceptowanych i pożądanych w życiu zbiorowym PRL, zaspokajając tym samym społeczny wymóg solidarności uczuć. Głoszenie ukrytych sądów aksjologicznych w stosunku do określonych osób i ich działalności społecznej, mające na celu uznanie przez odbiorcę przypisywanych im cech za prawdziwe ${ }^{21}$, często odbywa się przy użyciu emotywnie nacechowanych leksemów. W przypadku analizowanego materiału nie jest istotne, w jakich okolicznościach i do kogo zostały one skierowane, a to, jak się zmieniają - przyjmując coraz ostrzejszą formę wyrazu - w kolejnych księgach. A ponieważ nie dokonuję wyboru, lecz wymieniam wszystkie operatory emotywno-oceniające oraz bezpośrednie formuły opisowe, zwracam jednocześnie uwagę nie tylko na ich jakość, ale także na liczbę.

Księga I: gatgany; mistrz; zwycięzca; oszust; oferma; Co się wyglupiasz?

Księga IV: oferma batalionowa; Ale trafito mi się wojsko!; A'Tom odczepcie się!

Księga VIII: chudopachotki; frajer; Co on plecie?; gada bzdury

Księga XI: To ofiara!; Brakuje wam w głowach oleju [...]; Jazda z naszej budy!; Uważaj, harcerz, bo się usmarczesz!

Księga XVI: glupi; wariat; pomylony; superdebil; szajba mu odbita; To nie artykut... to chata!

Księga XVIII: skończony artysta; landszaft; potworek; pokraka; cwaniak; pomylony; wariat; ropucha; maszkara; Zghupiateś? Taki śmietnik, brudy, ohydztwo do piatej potęgi!

Zbyt mała liczba jawnie wyrażonych ocen, brak ich wyraźnego ukierunkowania ideologicznego nie uprawniają do poszukiwania w nich ukrytego sensu perswazyjnego. W tekstach niewiele jest również stanowiących wizytówkę stylu publicystycznego idiomów, operatorów analitycznych czy frazemów ( $O$ rety!; Wiwat!; A to pech!; Cie, choroba!; Tam do kata!; A nie mówitem!; A niech to molekuła!; Tego już za wiele). Na uwagę zasługują dopiero emotywnie nacechowane slogany, hasła i apele. Już na pierwszej stronie Księgi I Romek, zwracając się bezpośrednio do Tytusa, a pośrednio do dzieci, zachęca do członkostwa w Związku Harcerstwa Polskiego: „Przyłacz się do nas, nie marnuj młodości!" (s. 3). Kilkanaście stron dalej A’Tomek działa na rzecz „Świata Młodych”: „Czytajcie - natychmiast odmłodniejecie!” (s. 23). Księga IV to ukłon złożony w stronę polskiej armii: „Niech żyje Ludowe Wojsko Polskie!” (s. 54). W dobie budowania, gdy gospodarka nabiera rozpędu, A'Tomek w Księdze VIII powtarza

${ }^{21}$ Tamże, s. 258. 
hasło PZPR: „Dobra organizacja pracy to zwiększone efekty produkcyjne” (s. 4). Wraz z załamaniem się monopolu informacyjnego władz znikają z komiksów hasła o charakterze ideologicznym.

W kontekście postępujących zmian społeczno-kulturalnych można postrzegać również wzrastające przejawy potoczności języka, którym posługują się bohaterowie:

Księga I: fajne żelastwo [o mieczu].

Księga VIII: kupel z zoo; Ale wrobiliśmy Kopernika!

Księga XI: kapewu; ale fajno; Przez 23 godziny kombinowatem, jak zrobić zgrywę, aby się rozerwać.

Księga XVI: Uptynęly już 3 minuty nowego roku, a ja jeszcze nie zrobiłem żadnej hecy, czyżbym miat spóźniony zaplon humoru?

Księga XVIII: fifty-fifty; opylimy matpie obrazy; helot!; szmal; kapkę się zdrzemnąt. [podkreśl. A.Sz.]

Poddane analizie komiksy pozbawione są jakichkolwiek językowych przejawów patetyczności. Drugą, dużą grupę zachowań językowych wykorzystywaną do wywierania pożądanego wpływu stanowią frazemy blokujące weryfikację. Ich celem jest „uniemożliwienie lub znaczne ograniczenie weryfikacji przez odbiorcę prawdziwości wyrażonej asercji lub trafności dokonanej oceny"22. W sześciu poddawanych analizie księgach odnalazłam tylko jeden operator, odwołujący się do powszechnego stanu wiedzy oraz warunków szczerości danego aktu komunikowania się (A’Tomek: „Każdy harcerz powinien hodować jakieś zwierze”, s. 8), który „stawia odbiorcę w sytuacji niezręcznej do odrzucenia informacji jako niewiarygodnej" 23 .

Podsumowując dotychczasowe spostrzeżenia, dochodzę do wniosku, że Chmielewski nie dążył do zmian w postawach swoich odbiorców poprzez czysto językową perswazję. I chociaż uwielbiał posługiwać się utartymi zwrotami i frazami (ich bogactwo obserwujemy głównie w pierwszych księgach), to wykorzystywał je do utrwalania już istniejących wśród młodych ludzi postaw i ideałów. Wszechobecność powiedzonek, przysłów i mądrości ludowych to epatowanie swojskością, mające na celu przybliżenie najważniejszych problemów życia społecznego. Tym razem podaję już tylko wybrane przykłady zrytualizowanych zachowań komunikacyjnych z ksiąg I, IV, VIII, XI i XVI:

Księga I: Najadtem się strachu; Oddamy Zamek w dobre ręce; Wymówileś w zła godzinę!; Zemsta jest stodka!; Wsiakt jak kamfora!; Prawdziwego przyjaciela po-

${ }^{22}$ A. Awdiejew, Gramatyka interakcji werbalnej, Wydawnictwo Uniwersytetu Jagiellońskiego, Kraków 2007, s. 143.

${ }^{23}$ A. Awdiejew, G. Habrajska, Wprowadzenie..., s. 261. 
znaje się w biedzie; Mnie spadaja pieniadze z nieba; Stoi, ale na pewno duszę ma na ramieniu; Nie byt ciężki, miat pusto $w$ głowie; Śpiesz się powoli.

Księga IV: Byt uzbrojony po zęby; Ale najadłem się strachu!; Nie masz zielonego pojęcia o koszeniu; Kosi jak szatan!; Sam go uczyłem służby wartowniczej, a teraz jajko madrzejsze od kury.

Księga VIII: Zapat podwaja siły; Czmychajmy, gdzie pieprz rośnie; No, to 362 punkty regulaminu mamy już z głowy, to jest w głowach; krótkie włosy-krótki rozum.

Księga XI: Koniec. Nie mam dokąd uciekać, ale czy harcerz kiedykolwiek upada na duchu?; Nie ma chwili do stracenia!; poszedt w sina dal; A ja już jestem mądry i nie muszę trzymać się spódnicy zastępowego.

Księga XVI: Stoi jakby kij połknęła; uszczypnij mnie; Co się tak stroisz jak na wesele?

W Księdze XVIII przygód Tytusa, Romka i A'Tomka Papcio Chmiel nie zastosował ani jednego szablonu. Przyczyna rezygnacji z tej formy publicystycznej zdaje się być podyktowana rosnącym brakiem więzi społecznych i coraz bardziej dojmującym poczuciem klęski w społeczeństwie ${ }^{24}$. Do przeszłości odeszły już dawne szablony i klisze, a nowe, odpowiadające ówczesnym warunkom społecznym i ekonomicznym, nie zdążyły się jeszcze zrytualizować.

\section{Perswazja wywiedziona ze słowa}

Awdiejew i Habrajska w Komponowaniu sensu w procesie odbioru komunikatów tekstem nazywają ,wszystkie spostrzeżone przez człowieka komunikującego materialne komponenty komunikatu, które traktuje jako znaczące i wymagające dalszej interpretacji” ${ }^{25}$. Z proponowanej definicji jasno wynika, że teksty są zawsze informacyjnie niepełne, a ,uzupełnianie ich sensu wymaga wykorzystywania informacji znajdujących się w pamięci dyskursywnej interlokutorów"26. Tak więc zaistnienie tekstu Tytus, Romek i A'Tomek w świadomości odbiorcy rozpoczyna jego proces interpretacyjny, który, aby mógł przebiegać poprawnie i zakończyć się sukcesem (rozumianym jako odkrycie sensu komunikatu), musi bazować na kompetencji komunikacyjnej czytelnika. Umiejętność kojarzenia słów oraz ilustrujących je obrazków ze schematami wyobrażeniowymi nie zapewnia jeszcze zrozumienia przekazu. Najważniejszy komponent stanowi bowiem zdolność odbiorców do uzupełniania sensu wypowiedzi przez odwołanie się do kontekstu kulturowego, społecznego i politycznego.

${ }^{24}$ Historia polityczna świata XX wieku. 1945-2000, red. M. Bankowicz, Wydawnictwo Uniwersytetu Jagiellońskiego, Kraków 2004.

${ }^{25}$ A. Awdiejew, G. Habrajska, Komponowanie..., s. 8.

${ }^{26}$ Tamże, s. 10. 
Jedną z możliwości pozwalających na odkrycie sensu komunikatu jest odtworzenie ciągu argumentacji aksjologicznej. Papcio Chmiel, stosując w komiksach strategie aksjologiczno-emotywne, ułatwia czytelnikowi ten proces, jednocześnie wyraźnie go kształtując. Proponuje przyjęcie opinii wartościujących w stosunku do omawianych zdarzeń, nie stosując przy tym jawnej perswazji. W pierwszych księgach subtelnie podsuwa czytelnikom uogólnione sądy aksjologiczne, definiujące określone klasy obiektów wraz z ich atrybutami ${ }^{27}$. Odbiorca zaś poprzez zestawienie ze sobą owego uogólnionego sądu (reguła ogólna) z sądem dotyczącym konkretnego obiektu (sąd kwalifikujący) poszukuje oceny tego obiektu (konkluzja), którą ostatecznie przyjmuje za swoją. Oczywiście pod warunkiem, że akceptuje charakter ideologiczny argumentacji. I chociaż w teorii proces ten wydaje się skomplikowany, w praktyce umiejętność dokonywania kolejnych faz wyboru, doprowadzających ostatecznie do wniosków zgodnych z założeniami autora, jest „dziecinnie prosta”. Na przykład, w oparciu o pierwszą księgę przygód, można odtworzyć następujące ciągi aksjologiczne:

A'Tomek: Tytus, jak ty tak możesz caly dzień stać bezmyślnie przed brama?

Tytus: Caly dzień nie statem. Trochę siedziałem na murku.

A'Tomek: Myśmy przez ten czas urządzili podchody. Działaliśmy na szlaku niewidzialnej ręki... rozegraliśmy mecz...

Tytus: Tak? A ja myślatem, że harcerze to tylko zbieraja makulaturę!

Romek: Przyłącz się do nas, nie marnuj mtodości! (s. 3)

Reguła ogólna: Młody człowiek, który nie wykorzystuje wolnego czasu na zabawę w gronie przyjaciół i pomaganie innym, postępuje nagannie.

Sąd kwalifikujący: Tytus w wolnym czasie siedzi na murku lub stoi przed bramą. Konkluzja: Tytus postępuje nagannie.

Reguła ogólna: Nie należy brać przykładu z osób, których zachowanie jest niewłaściwe.

Sąd kwalifikujący: Postępowanie Tytusa jest niewłaściwe.

Konkluzja: Nie należy brać przykładu z Tytusa.

Reguła ogólna: Tylko przynależność do młodzieżowej organizacji gwarantuje właściwy rozwój młodego człowieka.

Sąd kwalifikujący: Romek i A’Tomek są harcerzami.

Konkluzja: Romek i A’Tomek odpowiednio kierują swoim życiem.

${ }^{27}$ A. Awdiejew, G. Habrajska, Strategie propagandowe i agitacyjne, [w:] Rozmowy o komunikacji 3, red. G. Habrajska, Oficyna Wydawnicza LEKSEM, Łask 2009. 
Reguła ogólna: Należy brać przykład z osób, których postępowanie uznawane jest za słuszne.

Reguła ogólna dopowiedzenia: Ten, kto odpowiedzialnie zarządza swoim czasem, jest godny naśladowania.

Sąd kwalifikujący - 1: Romek i A’Tomek poświęcają wolny czas życiu społecznemu.

Sąd kwalifikujący - 2: Romek i A'Tomek jako harcerze są godni naśladowania. Konkluzja: Należy wziąć przykład z Romka i A’Tomka i zapisać się do Związku Harcerstwa Polskiego.

W taki oto sposób młody człowiek dokonuje poprawnej interpretacji tekstu i dociera do zawartego w nim przesłania. Nieświadomie odtwarzane w umyśle reguły strategii aksjologiczno-emotywnych wpływają na wizję świata, nadając wyraźny kształt jego poglądom. W podobny sposób rekonstruuje on konkluzje dla innych, opisanych w tekście pod postacią reguł ogólnych i sądów kwalifikujących, zachowań i przekonań pożądanych społecznie. Uczy się wyśmiewać przesądy i zabobony, wykształca w sobie negatywny stosunek do alkoholu, docenia wartości wynikające z pracy na rzecz innych oraz pracy zarobkowej, nabiera chęci do uczestnictwa w różnego rodzaju inicjatywach harcerskich (Księga I), poznaje konieczność walki z wrogiem, przekonuje się o doniosłej roli Wojska Polskiego na froncie i poza nim (Księga $I V$ ), docenia czasy, w których nie brakuje osiągnięć naukowych i technologicznych (Księga VIII), potępia niszczenie zabytków, walczy z przesądami, opowiada się po stronie młodych ludzi zrzeszających się w państwowych organizacjach i stowarzyszeniach, jest przeciwny paleniu bez względu na okoliczności (Księga XI), pożąda wszelkiego rodzaju zdobyczy nowoczesnej technologii (Księga XVI i Księga XVIII).

Z każdą kolejną księgą możliwe do odtworzenia ciągi argumentacji aksjologicznej coraz częściej występują w postaci ukrytej: „Żeby wykryć zastosowany mechanizm argumentacji, należy dokonać standaryzacji argumentów"28.

A'Tomek: Zapalmy papierosy. Dym odstraszy komary.

A'Tomek: Tytus dlaczego nie palisz?

Tytus: Zwierzęta nie pala.

Tytus: A'Tom umiesz puszczać kótka?

A'Tomek: Zastępowy potrafi wszystko. Nawet z dymu zrobić własne imię!

Romek: A dlaczego Duszek nie robi dymu?

Duszek: Duchy nie pala, tak jak i zwierzęta.

Tytus: Co im się stało? Stracili przytomność! Woda ich nie ocuci. Zatruli się. (s. 56-57)

${ }^{28}$ A. Awdiejew, G. Habrajska, Wprowadzenie..., s. 267. 
Reguła ogólna: To, co nie jest dobre dla zwierząt, tym bardziej nie jest odpowiednie dla ludzi.

Sąd kwalifikujący: Zwierzęta nie palą.

Konkluzja: Człowiek nie powinien palić.

Reguła ogólna: Trucizny należy bezwzględnie unikać.

Sąd kwalifikujący: Papierosy to trucizna.

Konkluzja: Papierosów należy unikać.

Konieczność samodzielnej rekonstrukcji celu perswazyjnego zwiększa jego wyrazistość i uwiarygodnia przekaz, a także pomaga zwieść cenzurę. To, co nie jest wprost zakomunikowane, a jedynie otwiera pewne możliwości interpretacyjne, ma szansę zostać niedostrzeżone przez cenzora, a poprawnie (zgodnie z zamysłem autora) zinterpretowane przez czytelnika.

Reguła ogólna: Nieudolność władzy przejawia się między innymi w braku dbałości o estetyczny wygląd i czystość miast.

Sąd kwalifikujący: $A$, to teraz rozumiem, dlaczego w naszym mieście tyle śmieci. Większość mieszkańców to artyści.(s. 13)

Konkluzja: Władza jest nieudolna.

Jeszcze doskonalszą bronią w walce z polityką i politykami jest aluzja.

Skuteczność aluzji - dowodzą Awdiejew i Habrajska - polega na tym, że interpretacja jej sensu ukrytego jest zdobyczą odbiorcy. Dlatego właśnie oddziaływanie tego sensu jest silniejsze niż w przypadku bezpośredniego przekazu tej samej treści, a przy okazji chroni autora tekstu przed odpowiedzialnością za przekazaną informację, ponieważ może on zawsze powiedzieć, że nie miał na myśli tego, co zrozumiał odbiorca ${ }^{29}$.

Pomimo wyraźnie nakreślonych przez Wydawnictwo Harcerskie ram, opowieści o trójce bohaterów przemycają satyryczny obraz aktualnej sytuacji społecznej. Prawdziwie mistrzowska pod tym względem jest Księga XVI przedstawiająca - pod osłoną fikcyjnych przygód Tytusa w redakcji tygodnika „Trele Morele" - kulisy polskiego dziennikarstwa. Nie sposób w tym miejscu odnotować wszystkich krytycznych uwag, jakie padły pod adresem w pełni podporządkowanych władzy mediów. Poniżej, rezygnując ze szczegółowości na rzecz zwięzłości i komunikatywności wywodu, nie odtwarzam już ciągów argumentacji aksjologicznej, a jedynie rekonstruuję (na podstawie wymienionych przesłanek) konkluzję.

29 Tamże, s. 269. 
Konkluzja 1: Osoby pracujące w mediach nie mają odpowiedniego przygotowania merytorycznego i umiejętności niezbędnych w tym zawodzie.

Romek: A kto ci będzie poprawiat błędy ortograficzne?

Tytus: Dziennikarz nie musi znać ortografii. Wszystkie artykuty dyktuje bezbłędnej maszynistce. (s. 7)

Konkluzja 2: Informacje podawane przez media są fałszywe.

Tytus: Kiedy nie mamy co drukować, wypuszczamy kaczkę przez okno i ona przynosi nam wiadomości.

Tytus: Oto palec, z którego redaktorzy wysysaja wiadomości, jeśli brakuje im prawdziwych. (s. 32)

Konkluzja 3: Panuje ciche przyzwolenie na fałszowanie przekazu w imię wyższych celów.

A'Tomek: Te fatszywe zdjęcia nie bardzo sa zgodne z moim sumieniem... Chociaż ze względów pedagogicznych, chyba stuszne. Nie mam zdania... (s. 35)

Konkluzja 4: Poziom tworzonych tekstów nie odpowiada oczekiwaniom młodzieży.

Redaktor: To prochy nasenne dla paralityków, a nie numer dla mlodzieży! (s. 12)

Księga XVI jest dobitnym przykładem na to, że wypracowane w kulturze wzorce moralne i zachowania zostały zdegradowane, a ich miejsce w dyskursie społecznym zajmuje drwina $\mathrm{z}$ cenzury:

Obrońca: Miłościwy Panie! Afisz ten szkody nijakiej Waści uczynić nie może. Jak wiadomo, nikt z pospólstwa czytać nie umie. Przeto starczy Tytusa wybatożyć i pod pręgierzem potrzymać. A cenzurę wszystkiego, co się drukuje, na przyszlość wprowadzić. (s. 29) [podkreśl. A.Sz.]

oraz sarkazm:

Tytus: Okazuje się, że w redakcji tak samo tatwo o wypadek jak w dżungli. Dobrze, że nie spadlem z drabiny spolecznej. (s. 14) [podkreśl. A.Sz.] 


\section{Perswazja niezależna od słowa}

Odbiorca nie spotyka się z komiksem Tytus, Romek i A'Tomek w sposób przypadkowy. Pełni on rolę czytelnika, którego najważniejszym celem jest aktywne uczestnictwo w wymyślonym świecie, jego przeżywanie. We Wprowadzeniu do gramatyki komunikacyjnej czytamy: „takie uczestnictwo ma oczywiście charakter ludyczny, nie jest to uczestnictwo w realnym życiu” - i dalej - „zdolność do takiego uczestnictwa wynika z możliwości interpretacyjnych i wyobrażeniowych odbiorcy" ${ }^{30}$. W związku z tym, aby odbiorca mógł w pełni wniknąć w wyimaginowany świat, musi najpierw poznać reguły nim rządzące.

Czytelnik od samego początku ma świadomość, że głównym celem docierającego do niego komunikatu jest wywołanie rozbawienia. I chociaż obiekty komiczne oraz wydarzenia nie są realne, nie istnieją w rzeczywistym świecie, to w prawdziwym życiu występują podobne typy osobowości. Młodzi ludzie bez trudu odnajdują w swoim środowisku pierwowzory każdej z postaci. I tak: są „Tytusy” - zawsze działające w dobrej wierze, pomysłowe, niekonwencjonalne, odważne, butne i z ogromnym poczuciem humoru; są „Romki” - tchórzliwe, nerwowe, z poczuciem wyższości, bez skrupułów naśmiewające się z innych, artystyczne dusze; i są w końcu „A’Tomki” - perfekcjonistyczni przywódcy, nigdy nie „hańbiący się” pracą fizyczną.

Jak dowodzą badania procesu komunikacji, aby oddziaływanie było skuteczne, nadawca musi zdobyć zaufanie odbiorcy. Powstała wówczas między nimi więź znacznie osłabia sceptycyzm i ułatwia skuteczne wpływanie na poglądy, a w rezultacie na podejmowane przez odbiorcę decyzje i działania. Co zatem łączyło ówczesną młodzież z Tytusem? Umiejscowienie akcji w świecie stanowiącym odwzorowanie rzeczywistych realiów kulturalno-społecznych sprawiało, że czytelnicy identyfikowali się ze swoimi bohaterami na wielu płaszczyznach. Mieli podobne pragnienia, potrzeby i marzenia. Łączyło ich umiłowanie przygód, chęć obcowania z naturą, przynależność do organizacji młodzieżowych, ale również poczucie różnego rodzaju ograniczeń, niechęć do podporządkowywania się szkolnemu rygorowi, a nawet niemożność odnalezienia się w otaczającej rzeczywistości. Dlatego też promowane wzorce i postawy przyjmowali najczęściej z ufnością, a nawet bezrefleksyjnie. Ponadto młodzi ludzie nie zastanawiali się, kto stoi za ich komiksowymi kolegami. Nie spełniali oczekiwań państwa pod względem wychowania młodzieży, a tylko naśladowali lubianych bohaterów. Zresztą wśród propagowanych motywów znajdujemy zarówno takie, które są zgodne z ideologią epoki, jak również - głównie w późniejszych księgach - takie, które stanowią utajoną krytykę ustroju.

\footnotetext{
${ }^{30}$ Tamże, s. 293.
} 
Odwołując się do obserwacji poczynionych w oparciu o analizę zawartości i konstrukcję przekazu, wskazuję na perswazyjny charakter poszczególnych ksiąg. Przesłanie pierwszej księgi jest jednoznaczne: każdy młody człowiek powinien przynależeć do organizacji młodzieżowej. Oczywiście najlepszym wyborem jest Związek Harcerstwa Polskiego, harcerstwo bowiem oznacza przygodę. Trójka bohaterów Papcia Chmiela nie tylko uczestniczy we wszelkiego rodzaju działaniach ZHP, ale sama inicjuje wiele akcji (zakładają różne spółdzielnie, żeby zarobić na obóz). Naturalnie wszelkie przejawy samodzielności są zgodne z głównymi założeniami systemu. Epoka nie lubi „wychylania się”, o czym przekonuje się wielokrotnie Tytus, którego niekonwencjonalne działania nigdy nie wychodzą mu na dobre. Główna myśl zawarta na kartach Księgi IV stanowi rozszerzenie celu perswazyjnego z pierwszego komiksu. Tym razem bohaterowie bawią się w wojsko, a w nagrodę za zajęcie pierwszego miejsca w konkursie „Wojsko Polskie w rysunkach dzieci” zostają zaproszeni na prawdziwe ćwiczenia wojskowe. Księga ta to demonstracja siły i wielkości polskiej armii (sześć tablic z albumu A’Tomka) oraz zachęta, aby w dorosłym życiu przyłączyć się do niej, bowiem - w myśl propagowanych idei - służba dla kraju to zaszczyt i przyjemność, a nie obowiązek. W Księdze VIII dzieci nakłaniane są do uczestnictwa w pracach społecznych (Druhowie, spotkat nasz zaszczyt! Będziemy porzadkować miejsca, w których przebywat Mikołaj Kopernik, s. 3). Przekaz „pracujmy dla wspólnego dobra” zostaje wzmocniony przez wizję nowoczesnego, prężnie rozwijającego się kraju (obecna na rynku coca-cola, Warszawa pełna neonów). Piętnowane (a może wyśmiewane?) jest marnotrawstwo dóbr państwowych - ciężarówka odjeżdża na wysypisko załadowana jedną taczką gruzu. W Księdze XI obserwujemy ponowny już powrót do walki z przesądami i kolejne próby zachęcania młodzieży do aktywnego uczestnictwa w ZHP. Nawet Duszek musi gdzieś przynależeć:

A'Tomek: Trudna sprawa, bo my, harcerze, $w$ duchy nie wierzymy, a zamek możemy odbudować na harcówkę. Dobrze. Przyjmujemy cię do zastępu. Ale opowiedz swój zyciorys.

Romek: Raczej duchorys. (s. 8)

W komiksie pojawiają się także uszczypliwe komentarze, które choć oficjalnie kierowane do dawnych monarchistycznych władców, stanowią aluzję do współczesności: Oto z okazji rocznicy wycięcia migdatków księcia, będa potykać się rycerze... (s. 17). Ostatnie dwie z analizowanych ksiąg (XVI i XVIII) nie zawierają już wyraźnych przejawów PZPR-owskiej propagandy. W beztroski sposób donoszą o przejadaniu (dosłownie, bo pod postacią pączków) państwowego mienia, jak również swobodnie odwołują się do zachodnich motywów: 
Tytus: Siadajcie. Chcecie spróbować drinka?

Romek: Owszem.

A'Tomek: A ja dziękuję. Jestem harcerzem.

Tytus: To jest drink. Tu się naciska guzik, wtedy dzwoni: drink! drink! i można rozmawiać z redaktorami w innych pokojach.

Romek: Myślatem, że drink to coś do picia, tak jak na filmach. (s. 31)

Pomimo ogromnej dozy nowoczesności, wyrażającej się zarówno w szacie graficznej komiksu, jak i w doborze oraz sposobie organizowania treści, komiksy nadal pełnią funkcję dydaktyczną:

Romek: Za odzyskanie obrazu powinniśmy dostać jaką́ nagrodę.

A’Tomek: Ja narażam się dla kultury, nie dla nagród. (s. 61)

Coraz częściej jednak nie wskazują już na jedno, zgodne z powszechnie przyjętymi regułami rozwiązanie. Epoka „kształtowania młodych czytelników na odpowiedzialnych uczestników życia zbiorowego Polskiej Rzeczpospolitej Ludowej" powoli odchodzi w przeszłość. Teraz odbiorca sam decyduje, co należy zaakceptować, a co uznać za niepożądane i odrzucić. Nadchodzą czasy WOLNOŚCI:

Asizo: Masz szczęście. Będziesz świadkiem wielkiego wydarzenia artystycznego, czyli happeningu.

Tytus: To ma być sztuka?

Asizo: A nie jest sztuka zapalić taka duża zapalniczkę? (s. 41)

To, w jaki sposób owa wolność znajduje odzwierciedlenie w kompozycji kolejnych ksiąg z przygodami Tytusa, Romka i A’Tomka stanowi już problem na osobne studium. Niniejsze powstało, aby ukazać, jak proces interpretacyjny - będący w dużej mierze zautomatyzowanym odruchem - zostaje uwieńczony odkryciem perswazyjnego charakteru przekazu.

\section{Bibliografia}

Awdiejew A., Gramatyka interakcji werbalnej, Wydawnictwo Uniwersytetu Jagiellońskiego, Kraków 2007.

Awdiejew A., Komunikatywizm (perspektywa metodologiczna badań lingwistycznych), [w:] Język w komunikacji 1, red. G. Habrajska, Wydawnictwo Wyższej Szkoły Humanistyczno-Ekonomicznej, Łódź 2001.

Awdiejew A., Habrajska G., Komponowanie sensu w procesie odbioru komunikatów, Primum Verbum, Łódź 2010. 
Awdiejew A., Habrajska G., Strategie propagandowe i agitacyjne, [w:] Rozmowy o komunikacji 3, red. G. Habrajska, Oficyna Wydawnicza LEKSEM, Łask 2009.

Awdiejew A., Habrajska G., Wprowadzenie do gramatyki komunikacyjnej, t. 2, Oficyna Wydawnicza LEKSEM, Łask 2006.

Bonsiepe G., Retoryka wizualno-werbalna, „Pamiętnik Literacki” 1985, R. 76, z. 3., s. 303-309.

Chmielewski H.J., Tytus, Romek i A’Tomek. Księga I, Prószyński Media, Warszawa 2009.

Chmielewski H.J., Tytus, Romek i A’Tomek. Księga IV, Prószyński Media, Warszawa 2009.

Chmielewski H.J., Tytus, Romek i A’Tomek. Księga VIII, Prószyński Media, Warszawa 2009.

Chmielewski H.J., Tytus, Romek i A’Tomek. Księga XI, Prószyński Media, Warszawa 2009.

Chmielewski H.J., Tytus, Romek i A’Tomek. Księga XVI, Prószyński Media, Warszawa 2009.

Chmielewski H.J., Tytus, Romek i A’Tomek. Księga XVIII, Prószyński Media, Warszawa 2009.

Chmielewski H.J., Tytus zlustrowany. Autobiografia na tle historii komiksu pod tytułem „Tytus, Romek i A'Tomek”, Młodzieżowy Dom Kultury w Opolu, Opole 2006.

Historia polityczna świata XX wieku. 1945-2000, red. M. Bankowicz, Wydawnictwo Uniwersytetu Jagiellońskiego, Kraków 2004.

Paveau M.A., Sarfati G.E., Wielkie teorie językoznawcze. Od językoznawstwa historyczno-porównawczego do pragmatyki, tłum. I. Piechnik, Wydawnictwo AVALON, Kraków 2009.

Sowa A.L., Historia polityczna Polski 1944-1991, Wydawnictwo Literackie, Kraków 2011.

Anita Szwajkowska

\section{Comic book series „Tytus, Romek and A'Tomek” in perspective of Communicativism}

\section{(Summary)}

Author analyses six selected comic books from popular series „Tytus, Romek \& Atomek” by Henryk Jerzy Chmielewski, using unique communicativistic theory discovered by G. Habrajska and A. Awdiejew. She's searching some verbal and non-verbal determinants, which are typical for the publicistic style (persuasion closed in words, persuasion extracted from words, self-contained persuasion). The effect of this research is a fact, that the comics by Chmielewski (primary classified as an artictic style) - has its characteristic persuasive purpose, through using all the elements of the publicistic discourse. According to that, the main purpose of the comics was: to indoctrinate young readers as the responsible participants of the community in Polish People's Republic.

Keywords: communication study, an axiological meaning, sense, the axiological and emotive strategies, persuasia. 